\title{
Effect of vitamins $\mathrm{E}+\mathrm{C}$ and taurine on the oxidative state of DNA in the liver of growing pigs*
}

\section{E. Sawosz ${ }^{1,3}$, A. Strawa', A. Chwalibog ${ }^{2}$, T. Niemiec' ${ }^{1}$, I. Kosieradzka' and I. Dudkowska'}

\author{
'Department of Animal Nutrition and Feed Science, Warsaw' Agriculiural University \\ Ciszewskiego 8. 02-786 Warsaw, Poland \\ 2Department of Animal and Veterinary Basic Sciences, \\ The Royal Veterinany and Agricultural University \\ Bülowsvej 13, Frederiksberg C. Denmark
}

\begin{abstract}
Growing pigs ( $\mathrm{n} 2 \mathrm{i}$ ) at an initial liveweight of $30 \mathrm{~kg}$ were divided into three groups of 7 animals each and housed in individual cages for 100 days. The pigs were fed with similar diets (13.5 MJ ME and $178 \mathrm{~g}$ crude protein $/ \mathrm{kg}$ ) but with different additions of vitamins $\mathrm{C}+\mathrm{E}$ and taurine.

The antioxidative vitamins $\mathrm{E}$ and $\mathrm{C}$ supplied to diets with high energy concentrations (containing lard) can act as pro-oxidants on liver DNA in growing pigs. Taurine decreased the concentration of products from nucleotide oxidation, but in the presence of vitamin $\mathrm{F}$. and $\mathrm{C}$, promoted hepatocyte lesions.
\end{abstract}

KEY WORDS: pigs, vitamin E, vitamin C., taurine, DNA oxidation

\section{INTRODUCTION}

A high concentration of energy and protein in the diet can enhance the rate of energy metabolism, activity of electron transport in the mitochondrial respiratory chain and cause an increase in the synthesis of Reactive Oxygen Spccies (ROS) (Weindruch, 2002). ROS enhance the destruction of lipids, proteins, carbohydrates and DNA. Oxidative DNA damage leads to formation of 8-oxo-2deoxyguanosine, an adduct that occurs in DNA and causes mutagenesis (Helbock et al., 1998). Vitamin $E$ prevents lipid peroxidation while vitamin $C$ reduces the tocopheryl radical to its active form, tocopherol. It can be expected that a complex antioxidative system requires an antioxidant affiliated with DNA and therefore taurine, mainly taurine's amino group, which is strongly associated with DNA, can be one of the potential antioxidative agents protecting DNA. However,

\footnotetext{
"Supported by the State Committee for Scientific Research, Grant No. 6 P06 E02720

${ }^{3}$ Cortesponding author: e-mail: sawosz@alpha.sggw.waw.pl
} 
unlimited supply of antioxidants can activate pro-oxidative processes resulting in an imbalance in redox homeostasis. The objective of this study was to determine the effects of vitamins $\mathrm{E}$ and $\mathrm{C}$ and taurine on the oxidative state of DNA in relation to antioxidative/oxidative indicators of redox homeostasis in growing pigs as a model for humans.

\section{MATERIAL AND METHODS}

Pigs ( $30 \mathrm{~kg} \mathrm{BW} ; 3$ groups $\times 7$ animals) were housed in individual cages for 100 days, and fed with similar diets (13.5 MJ ME and $178 \mathrm{~g}$ crude protein $/ \mathrm{kg}$ ) containing, \%: barley, 63; wheat, 10.0; soyabean meal, 13.5; meat-and-bone meal, 5.0; lard, 7.0; L-lysine, 0.12; DL-methionine, 0.018; vitamin-mineral mixture, 0.5 , but with different additions of vitamins: $\mathrm{C}$ (natrium ascorbinate) 0.1 ; E ( $\alpha$-tocopherol acctate), 0.2 , and taurine, 0.5 .

At the end of the experiment the animals were fasted for $12 \mathrm{~h}$ and blood was sampled from the heart. Thiobarbituric acid reactive substances (TBARS) were measured with 1.2.3.3-tetraethoxypropane (TEP) as the standard by a colorimetric method. Activities of superoxide dismutase (SOD) and glutathione peroxidase (GPx) were analysed by Randox Laboratories Ltd. kits at $37^{\circ} \mathrm{C}$ in a COBAS FARA II analyser. 8-oxo- $2^{\circ}$-deoxyguanosine (8-oxo-dG) and 2 '-deoxyguanosine were determined using a Dionex HPLC with electrochemical (at $350 \mathrm{mV}$ ) and UV (at $254 \mathrm{~nm}$ ) detectors and a $250 \times 4.6 \mathrm{~mm}$ Supclcosil LC$18-\mathrm{S}$ column ( $5 \mu \mathrm{m}$ grain). The amount of 8 -oxo-dG in DNA was calculated as the number of 8 -oxo-dG molecules $/ 10^{\circ}$ unmodified $\mathrm{dG}$ molecules. Albumin, total bilirubin, glucose, asparagine transferase (AST) and alanine transferase (ALT) were determined using Vitros DT II (Johnson and Johnson, USA).

The results were subjected to statistical analysis by monofactorial ANOVA and Duncan's range test, using the Statgraphic 4.1 Plus software package.

\section{RESULTS AND DISCUSION}

The addition of antioxidants increased the activity of SOD. This enzyme catalyses the dismutation of the superoxide radical $\left(\mathrm{O}_{2}^{-}\right)$which is produced by single electron reduction of oxygen, especially in the mitochondrial respiratory chain (Sohal et al., 1995). Dietary antioxidants support the system of defence against ROS in cells, which could lead to SOD protection.

Serum albumins belong to major antioxidants. The elevated serum albumin concentrations and decreased $\mathrm{NO}_{3}$ concentrations in pigs receiving antioxidants may suggest that the degradation of the cell structure was associated with the water phase and thereby protecting a protein fraction. However, feeding diets supplemented with antioxidants $\mathrm{E}$ and $\mathrm{C}$ (group II) significantly affected the oxidations of 
2-deoxyguanosine $(\mathrm{dG})$ at the $\mathrm{C}-8$ position, which led to an increased concentration of 8-oxodG in liver DNA. These results confirm earlier results (Niemiec and Sawosz, 2004) regarding the pro-oxidative function of vitamin $\mathrm{C}$ in rats. Vitamin $\mathrm{C}$ can increase generation of "OH in a superoxide anion-driven, redox active $\mathrm{Fe}^{2+}$ catalysed, Fenton reaction. DNA is highly resistant to $\mathrm{O}_{2}^{-}$or $\mathrm{H}_{2} \mathrm{O}_{2}$, while sensitive to the hydroxyl radical $(\mathrm{OH})$. However, it is likely that reduced transition metal ions, mainly $\mathrm{Fe}$ (II) and $\mathrm{Cu}$ (II) can inhibit the activities of 8-oxo-2'deoxyguanosine 5 'triphosphate pyrophospho-hydrolase (8-oxo-dGTPase), (Kasprzak el al., 1999). This enzyme termed an antimutagenic, "sanitizes" the cellular nucleotide pool (Mo et al., 1992) and prevents incorporation of 8-oxo-dG into DNA. The presence of 8-oxodG in the DNA template was observed in liver disease (Kitada et al., 2001) and may stimulate mutagenesis and cancerogenesis (Shibutani et al., 1991).

The addition of taurine (Group III) could counteract the negative effects of vitamin $C$ because the concentration of 8-oxodG in liver DNA was significantly lower than in Group II, and was similar to Group I. The amine group of taurine has a high affinity to DNA. Redmond et al. (1998) demonstrated that taurine protected DNA against ROS generated by respiratory bursts in neutrophils. However, the activities of ALT and total bilirubin in the serum of pigs receiving vitamins $E+C$ and taurine (Group III) increased, which may be indicative of hepatocyte lesions.

TABLE 1

Concentration of 8-oxo-2'-deoxyguanosine in the liver and biochemical parameters in peripheral blood of rats

\begin{tabular}{|c|c|c|c|c|c|}
\hline \multirow[b]{2}{*}{ Parameters } & \multicolumn{3}{|c|}{ Group } & \multicolumn{2}{|c|}{ ANOVA } \\
\hline & $\begin{array}{c}\text { Control } \\
\text { I }\end{array}$ & $\begin{array}{c}\text { CE } \\
\text { II }\end{array}$ & $\begin{array}{c}C E+T \\
\text { III }\end{array}$ & SEM & $\mathrm{P}$ \\
\hline 8-oxo-2'-deoxyguanosine, 8 oxod G/106 $\mathrm{Dg}$ & $7.79^{\mathrm{a}}$ & $10.30^{b}$ & $8.16^{4}$ & 0.580 & 0.0133 \\
\hline Thiobarbituric acid reactive substances, $\mu \mathrm{mol} / \mathrm{L}$ & 1.97 & 1.78 & 1.91 & 0.547 & 0.0547 \\
\hline $\mathrm{NO}_{3}^{-}, \mu \mathrm{mol} / \mathrm{L}$ & $20.5^{a}$ & $3.98^{\mathrm{h}}$ & $5.73^{\mathrm{h}}$ & 4.271 & 0.0303 \\
\hline Supcroxide dismutase, $\mathrm{U} / \mathrm{gHb}$ & $329^{a}$ & $436^{h}$ & $435^{\mathrm{h}}$ & 22.7 & 0.0480 \\
\hline Glutathione peroxidase, $\mathrm{U} / \mathrm{gHb}$ & 49.2 & 60.6 & 49.2 & 4.58 & 0.1577 \\
\hline Albumin, $g / L$ & $40.1^{\mathrm{a}}$ & $43.0^{\mathrm{b}}$ & $43.9^{h}$ & 0.930 & 0.0289 \\
\hline Total bilirubin, $\mu \mathrm{mol} / \mathrm{L}$ & $7.0^{\mathrm{a}}$ & $8.3^{\mathrm{a}}$ & $15.3^{\mathrm{h}}$ & 0.73 & 0.0000 \\
\hline Glucose, $\mathrm{mmol} / \mathrm{L}$ & 4.6 & 5.4 & 5.3 & 0.53 & 0.5218 \\
\hline Asparagine transferase, $\mathrm{U} / \mathrm{L}$ & 36.7 & 43.6 & 63.9 & 9.42 & 0.1346 \\
\hline Alanine transferase, U/L & $57.0^{\mathrm{a}}$ & $70.4^{\mathrm{sth}}$ & $83.6^{\mathrm{h}}$ & 6.65 & 0.0362 \\
\hline
\end{tabular}

${ }^{\text {ab }}$ means with different superscripts are significantly different $(\mathrm{P}<0.05)$

\section{CONCLUSIONS}

Antioxidative vitamins $\mathrm{E}$ and $\mathrm{C}$ supplied to dicts with a high concentration of energy (containing lard) can act as pro-oxidants on DNA in growing pigs. However, 
taurine decreases the concentration of oxidative stress-related compounds involving products from nucleotide oxidation, but in the presence of vitamins $\mathrm{E}$ and $\mathrm{C}$ may contribute to liver damage.

\section{REFERENCES}

Helbock H.J., Beckman K.B., Shigenaga M.K., Walter P.B., Woodall A.A., Yeo H.C., Ames B.N., 1998. DNA oxidation matters: The HPLC-electrochemical detcetion assay of 8-oxodeoxyguanosine and 8-oxo-guanine. Proc. Nat. Acad. Sci. USA 95, 288-293

Kasprzak K.S., Bal W., Porter D.W., Białkowski K., 1999. Studies on oxidative mechanism of metal-induced carcinogenesis. In: Dizdaroglu, Karakaya (Editors). Advances in DNA Damage and Repair. Kluwer Academic Plenum Publishers, Ncw York, pp. 193-207

Kitada T., Seki S., Iwai S., Yamada I., Sakaguchi HI., Wakasa K., 2001. In situ detection of oxidative DNA damage 8-hydroxydcoxyguanosine in chronic human liver disease. J. Hepatol. 35, 613618

Mo J.Y., Maki H., Sekiguchi M., 1992. Hydrolytic elimination of a mutagenic nucleotide 8-oxodGTP by human 18-kilodalton protein: Sanitization of nucleotide pool. Proc. Nat. Acad. Sci. USA $89,11021-11025$

Niemice 1., Sawosz E., 2004. Effect of addition of L-ascorbic acid megadoses to the dict on the antioxidative/oxidative state in the rats. Proccedings of European Society of Veterinary and Comparative Nutrition. Budapest, pp. 258-259

Redmond II.P., Stapleton P.P., Neary P., Bouchier-Ilayes D., 1998. Immunonutrition: The role of taurine. Nutrition 14, 599-604

Shibutani S., Takeshita M., Grollman A.P., 1991. Insertion of specific based during DNA synthesis past the oxidation-damage base 8-oxodG. Nature 349, 431-434

Sohal R.S., Sohal B.I1., Orr W.C., 1995. Mitochondrial superoxide dismutase and hydrogen peroxide generation. Protein damage and longevity in diflerent specics of flies. Free Radical Biol. Med. 19, 499-504

Weindruch R., 2002. Caloric intake, oxidative stress and aging. Free Radical Biol. Med. 33, Suppl. 2. $\$ 169$

\section{STRESZCZENIE}

\section{Wpływ dodatku witamin E+C oraz tauryny na utlenienie DNA w wątrobie rosnących świń}

Rosnące świnie ( $\mathrm{n}=21$, o m.c. $30 \mathrm{~kg}$ ) podzielono na 3 grupy po 7 s7tuk $\mathrm{i}$ utrzymywano $w$ indywidualnych klatkach przez. 100 dni. Tuczniki otrzymywały izoenergetyc zną i izobiałkowa dietę z udziałem różnych dodatków: witamin $\mathrm{E}$ i $\mathrm{C}$ oraz witamin $\mathrm{E}+\mathrm{C}$ i tauryny.

Witaminy antyoksydacyjne dodawane do diety o wysokicj koneentracji energii (dodatek smalcu) wykazywaly prooksydacyjne d ziałanie $w$ stosunku do DN $\wedge$ wątroby swiń. Tauryna wpłynęla na zmniç̣s $/$ mie koncentracji produktów oksydacji nukleotydów w wątrobie, wraz $z$ witaminami $\mathrm{E}$ i C spowodowata uszkodzenie miązszu wąlroby. 